\title{
Need of The Ministry of Health in Federal Democratic Republic of Nepal
}

\author{
Kiran Regmi, ${ }^{1}$ Meera Upadhyay, ${ }^{2}$ Ehsanullah Tarin, ${ }^{3}$ Padam Bahadur Chand, ${ }^{4}$ Senendra Raj Uprety, ${ }^{5}$ Susheel \\ Chandra Lekhak ${ }^{2}$ \\ 'Health Secretary, Ministry of Health, Government of Nepal, Kathmandu, Nepal, ${ }^{2}$ National Professional Officer, WHO \\ Country Office Nepal, Lalitpur, Nepal, ${ }^{3}$ Health Systems Strengthening, Consultant WHO Country Office Nepal, Lalitpur, \\ Nepal, ${ }^{4}$ Advisor, Ministry of Health, Government of Nepal, Kathmandu, Nepal, ${ }^{5}$ Ex-Health Secretary, Ministry of Health, \\ Government of Nepal, Kathmandu, Nepal.
}

\section{ABSTRACT}

The constitution of Nepal provides appointing a council of ministers both at federal and provincial levels without defining portfolios. There is a political agreement that $\mathrm{MOH}$ will be retained at the federal level. This article draws evidences around the world to meet health needs of Nepalese, the role of provincial ministry of health and coordinating structure at district/local level.

The constitution emphasises on health and pronounced in 46 articles which provides guidance for the creation of federalized governance levels at federal, provincial and local levels. Retaining ministry of health at federal level without creating devolved structure at province and local levels in health sector will create difficulty in translating the spirit of the constitution and may not be effective in addressing health issues nationally and meeting global achievements like SDGs.

It is suggested to establish an elaborate health system accordingly in Nepal to ensure constitutional mandate of health as a basic human right.

Keywords: constitution; federalism; health sector; ministry of health.

\section{INTRODUCTION}

A new constitution of Nepal ${ }^{1}$, promulgated in September 2015, declared the country as a federal republic with three autonomous governance levels: the federation (national), the province, and the local level, each have an elected assembly. Government decision of having Ministry of health has shown lots of hope to fulfil the constitution's directions towards Health as a basic human right of people. However, it is not yet clear on its existence at provinces.

In order to bring evidence, a rapid review of the health sector organisation and management in Nepal was undertaken. Data was collected qualitatively and the contents and wording of the Constitution was studied in depth. Second, the data and experiences from other countries on the role of their $\mathrm{MOH}$ were collected. Third, brainstorming sessions and informal discussions with key informants were held to solicit views about the roles of the $\mathrm{MOH}$ and the possible impact of changes. Data were analysed manually and verified with key informants.

\section{WHAT ARE THE CONSTITUTIONAL PROVISIONS OF HEALTH IN NEPAL}

The constitution lays great emphasis on health. The constitution envisions a Federal Democratic Republic of Nepal, inter-alia, as a socialism-oriented state. It lays

Correspondence: Dr. Meera Upadhyay, National Professional Officer, WHO Country Office Nepal, Lalitpur, Nepal. Email: meeraupadhyay5@gmail.com, Phone:+977-9851057877. 
great emphasis on citizens' rights including to health and requires the State to ensure basic needs. The federated units have powers to make policy, generate and utilize resources locally, and draw its rules, albeit within the guidelines and not inconsistent with the provisions of the federal law. ${ }^{1}$ Table 1 provides a summary of the constitutional provisions related to health.

Table 1. Constitutional provisions related to health.

\begin{tabular}{|c|c|c|c|c|c|c|c|c|c|}
\hline \multirow[b]{2}{*}{ Total } & \multicolumn{4}{|c|}{$\begin{array}{l}\text { General directions for the "State of } \\
\text { Nepal" }\end{array}$} & \multicolumn{3}{|c|}{ Delegated (exclusive) powers } & \multicolumn{2}{|c|}{ Concurrent powers } \\
\hline & $\begin{array}{l}\text { Rights } \\
\text { based }\end{array}$ & $\begin{array}{l}\text { Basic } \\
\text { Needs }\end{array}$ & $\begin{array}{l}\text { Social } \\
\text { justice }\end{array}$ & $\begin{array}{l}\text { Invoking } \\
\text { health } \\
\text { emergency }\end{array}$ & $\begin{array}{l}\text { Federal } \\
\text { (Sch. 5) }\end{array}$ & $\begin{array}{l}\text { Provl. } \\
\text { (Sch. -6) }\end{array}$ & $\begin{array}{l}\text { Local } \\
\text { (Sch. -8) }\end{array}$ & $\begin{array}{l}\text { Federal + } \\
\text { Provl (Sch. } \\
-7 \text { ) }\end{array}$ & $\begin{array}{l}\text { Federal }+ \text { Provl }+ \\
\text { Local (Sch. -9) }\end{array}$ \\
\hline 46 & 15 & 8 & 3 & 1 & 3 & 5 & 3 & 5 & 3 \\
\hline
\end{tabular}

Given the above provisions, the "will of the constitution" seems to emphasize the importance and value of health in the state structure. From this, it seems logical that the response of the government of Nepal should be proportionate. It is difficult to imagine that all healthrelated provisions stipulated in the constitution could be implemented without a strong central and provincial entity to guide, oversee, coordinate, and remain accountable.

\section{WHAT WAS THE SCENARIO BEFORE FEDERALISATION?}

Prior to federalisation, functions were performed by transferring responsibility to lower tiers in health sector hierarchy within the central government bureaucracy.

In a deconcentrated system (Chart 1) the case prior to the promulgation of new constitution the central Ministry of Health $(\mathrm{MOH})$ had control over the peripheral hierarchy of the health sector (Figure 1). There was a division of labour in a manner that responsibility for specified functions was transferred to the lower levels within the central government bureaucracy without authority for policy, financial and administrative matters.

Federalism, akin to devolution, is "transfer of decisionmaking authority from centre to the legally incorporated local governments, like provinces, districts or municipalities".1 The provincial and local levels can establish structures to exercises powers and perform functions assigned under law.

In Nepal, (Chart 3) current constitution provides creation of three federalized governance levels: federal, provincial, and local or village/municipality level. Each of these levels has an elected assembly with powers to frame law, raise and appropriate revenue and manage affairs. However, the district, which had a role in health system is absent from hierarchy of the federated governance. Instead, village bodies, i.e. municipalities and district assemblies are established as local level; and District Assembly shall consist of Chairpersons and
Vice-Chairpersons of Village Executives, and Mayors and Deputy Mayors of Municipal Executives within the districts. A District Coordination Committee will draw its members from District Assembly and will be established at each district. District Coordination Committee may be worth to establish in each district a District Health Sector Coordination Committee, as a de-concentrated unit of the province for technical and managerial support to local health care system. A council of ministers will be appointed at federal and provincial levels respectively. There arises a bigger question, on existence of a ministry of health at provincial level? In order to deliberate and guide on this issue, two committees appointed by the government, reportedly, saw no need. While there is no discussion about provincial ministry of health, the said committees suggested lumping of $\mathrm{MOH}$ with sectors like education, employment, etc. The uncertainty remains about separate provincial $\mathrm{MOH}$. For effective deliverance of health functions the need for $\mathrm{MOH}$ at province level is equally important. A coordination structure at district/local level is another necessity for making health system strong.

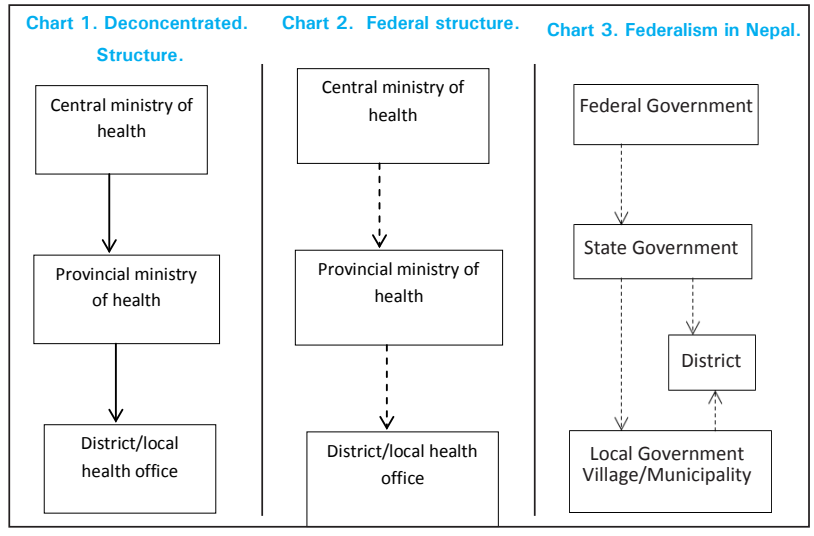

In Nepal, the healthcare delivery network is extensive, and extends from specialized hospitals in capital cities, to secondary care hospitals at districts, primary care facilities in villages and outreach services. The current dedicated ministry of health, which is organised at national, regional, zonal district and local levels, 
CENTRAL LeVEe

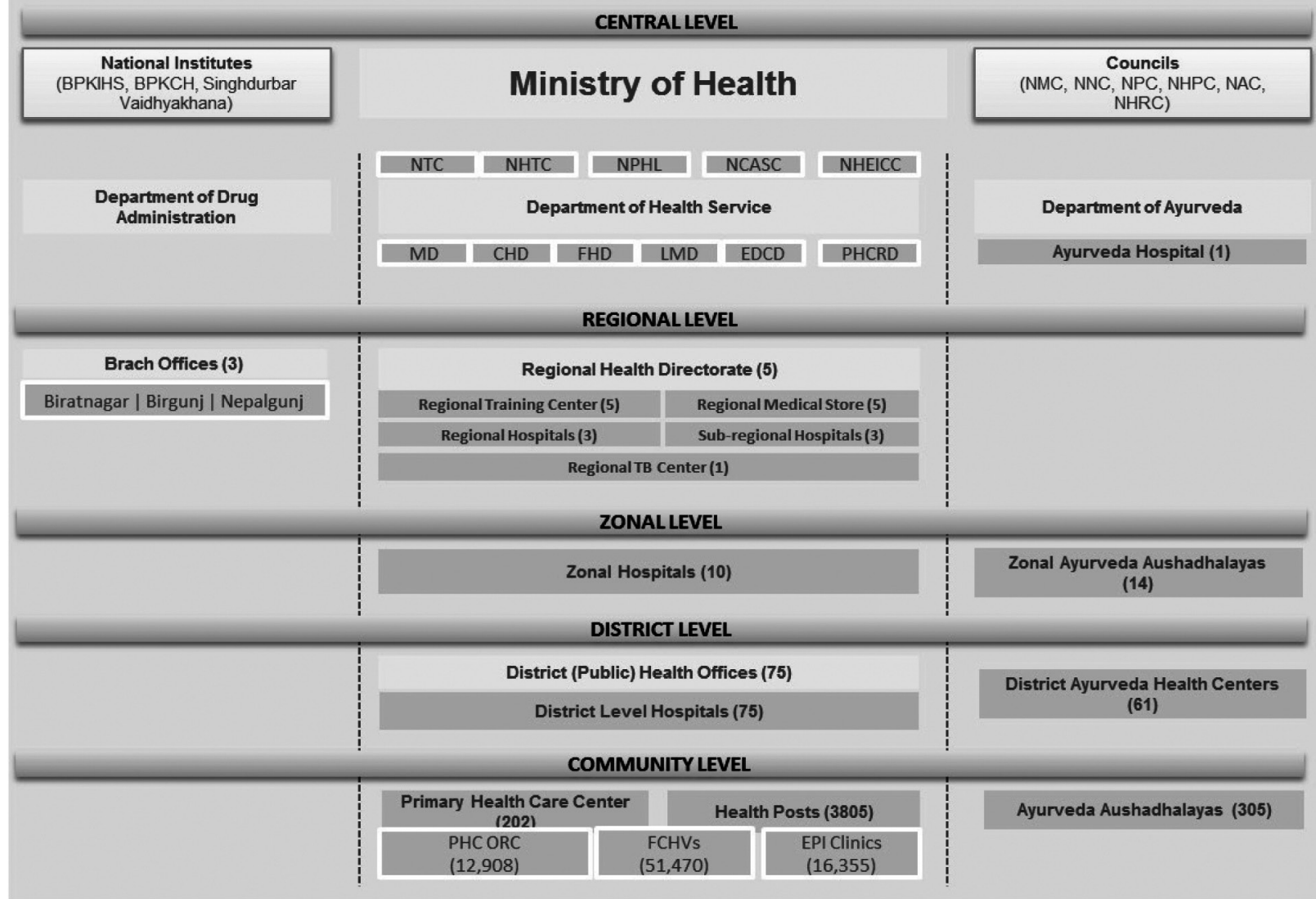

Figure 1. Organogram of the Ministry of Health (prior to federalization).

\section{THE NECESSITY OF IMINISTRY OF HEALTH}

\section{- To address health sector resources and challenges}

The $\mathrm{MOH}$ also needs to address the challenges posed by the insufficient levels of total health expenditure and the high out of pocket household health spending. Furthermore, the mix of communicable diseases, noncommunicable diseases (cardiovascular diseases, cancers, diabetes, chronic respiratory diseases, mental health, and injuries) and the health impact of the country's natural emergencies and disasters require more specialized attention.

In terms of human resources, a total of 54,177 health workers provide services across public and private health sectors. It is not clear how the health sector and its resources, which are enormous, will be managed, once the federal structure will be introduced.

The health agenda extends beyond health sectors, having direct or indirect implications. The WHO
(1978) Declaration for Primary Health Care, which reiterated as 'health in all policies. Sustainable Development Goals (SDGs) require a multi-sectorial approach having inter-linked goals. This is in order to seek the availability of a strong organization with technical know-how, i.e. the $\mathrm{MOH}$, capable to lead coordination and collaboration between sectors is essential to guarantee synergies, avoid harmful health impacts, and improve population health and health equity.

- To fulfill the global comitments made

Nepal made significant gains in achieving the healthrelated Millennium Development Goals (MDGs). The SDGs and especially Goal 3 ("Ensuring healthy lives and promoting well-being for all people of all ages") continue that legacy and its unfinished agenda, and further expand it.

Nepal has set SDG-related targets that require acceleration and expansion of health interventions and 
strong monitoring that will ultimately lead to universal health coverage (UHC). With its experience in advancing towards the MDGs, it is the $\mathrm{MOH}$ that is best placed to also lead the health agenda of the SDGs.

- To align and harmonise external development partners

In Nepal, the Ministry of Health is financially and technically supported by external development partners (EDPs). In 2016-2017, the EDPs contributed almost $25 \%$ to the $\mathrm{MOH}$ budget. At the technical level, the EDPs have aligned their activities and support with different sections of $\mathrm{MOH}$ and also harmonized amongst themselves for aid effectiveness. A Health Forum and Joint Annual Reviews (JAR) are two of several mechanisms to ensure coordination and alignment.

This collaborative mechanism has evolved over several years, often after negotiations between stakeholders. Any change in how the health sector is organised means the EDPs will need to re-align, re-harmonize and reestablish the coordination and monitoring mechanisms, which in its own right could be a big challenge without having a national leader organization in health.

\section{- To manage a specialised sector}

Countries have obligations not only for the health of their own people and populations, but also for the international community. For example, under the International Health Regulations (IHR) (WHO, 2005), of which Nepal is a signatory, countries have an obligation to notify WHO of events that may constitute a public health emergency of international concern. Nepal has also committed to various global initiatives, which require international coordination and communication. To organise and manage such issues, a strong specialised structure or a dedicated ministry of health needs to be established as part of the country's governance at federal as well as at the provincial levels.

\section{THE GLOBAL EVIDENCES ON FEDERALISATION}

\section{- Trend around the globe for establishing ministry of} health

- Data from 194 countries that are members of the World Health Organization were analysed. Out of these,) 143 or $74 \%$ countries have a dedicated $\mathrm{MOH}$ or ministry of public health, while 46 or $24 \%$ countries have $\mathrm{MOH}$ that has other sectors together with it (Figure 2). It was only 5 or $2 \%$ countries, which have health represented as a sub-sectoral unit. That is, with three quarters of countries around the world having a dedicated ministry, the health is considered sufficiently important and prioritised in their governance structure.

- Population as a determinant in placing health in governance structure

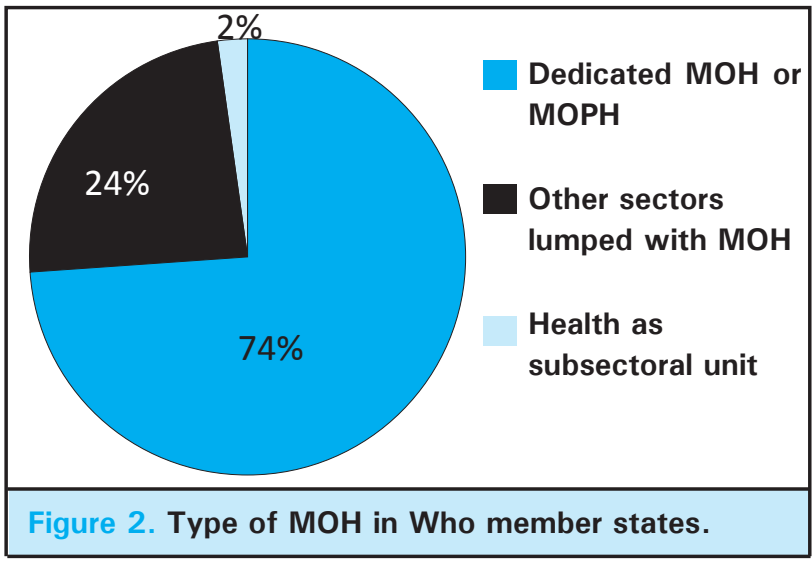

We analyzed whether population could influence how health is placed in the country's governance structure? In order to address this question population data vis-àvis the status of health in government were analysed. Nepal's population, i.e. 28.5 million people, was used as an index. From around the world, 14 countries (Annex-3), excluding Nepal, have a population in the range of $28.5 \pm 5$ million (i.e. 23.5 to 33.5 million). It was found that 11 or $79 \%$ of these countries (Figure 3 ), have a dedicated ministry for health (or public health), while 3 or $21 \%$ have other social sectors, like population (1), aged care (1), family planning (1), additional with $\mathrm{MOH}$.

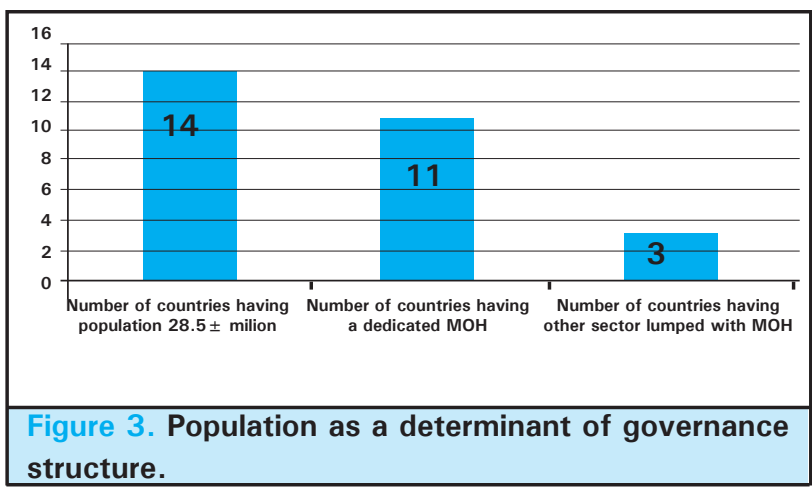

This trend is maintained, when data from all countries having population $\leq 28.5$ million is analysed vis-à-vis the type of $\mathrm{MOH}$. As in Figure 4, 148 countries around the world have population equal or less than Nepal. Out of these 108 or $73 \%$ have dedicated ministry of health, 35 or $24 \%$ have other sectors lumped with ministry of health, while 5 or $3 \%$ countries have health at the subsectoral level of governance. That is, it can be inferred from the above that population of a country is not a significant factor in designing the governance structure, 
and particularly how health is placed in the organogram of the council of ministers. Countries, irrespective of the population size, in overwhelming number, have a dedicated ministry of health and/or designed a ministry by lumping allied sectors with health

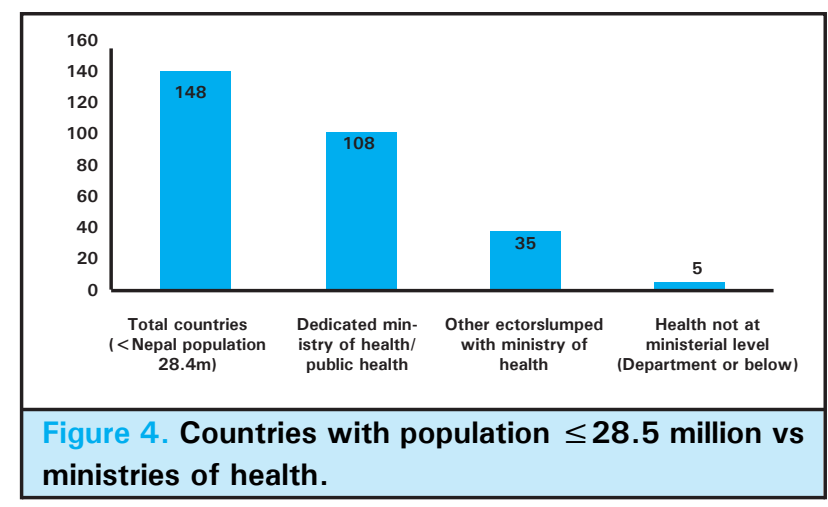

This trend is maintained, when data from all countries having population $\leq 28.5$ million is analysed vis-à-vis the type of $\mathrm{MOH}$. As in Figure 4, 148 countries around the world have population equal or less than Nepal. Out of these 108 or $73 \%$ have dedicated ministry of health, 35 or $24 \%$ have other sectors lumped with ministry of health, while 5 or $3 \%$ countries have health at the subsectoral level of governance. That is, it can be inferred from the above that population of a country is not a significant factor in designing the governance structure, and particularly how health is placed in the organogram of the council of ministers. Countries, irrespective of the population size, in overwhelming number, have a dedicated ministry of health and/or designed a ministry by lumping allied sectors with health

- Influence of federal governance on shaping the ministry of health

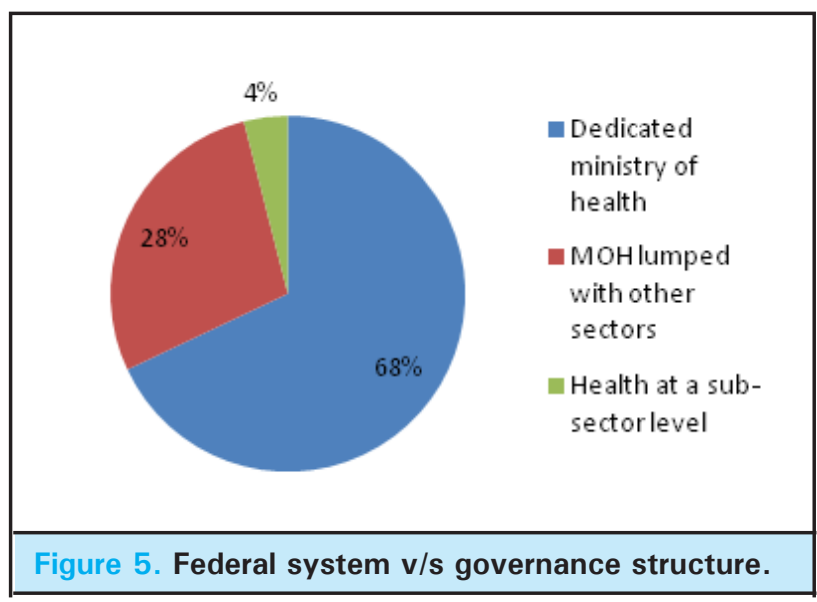

The analysis so far involved the countries and their population irrespective of the governance system. How does a federal system affect in placing health in country's governance? Excluding Nepal, 25 countries were identified around the globe that has federal system of governance. Out of these, 17 or $68 \%$ countries, as in Figure 5, have a dedicated ministry of health, while in 7 or $28 \%$ have other sectors added with health. In case of only one or $4 \%$ countries, health is a sub-sector or department of another ministry. Thus, the majority two third of countries (68\%) with federal system have a dedicated ministry of health. These results, to a larger extent, are comparable to the trend observed in countries irrespective of the political system; federal or unitary (see above).

\section{SUMMARY OF COUNTRIES REVIEW}

It revealed, countries kept health on forefront while designing governance structure, irrespective of political structure and population (Table 1).

Table 1. Summary of findings from countries' review.

\begin{tabular}{|c|c|c|c|c|}
\hline $\begin{array}{l}\text { Study } \\
\text { variable }\end{array}$ & Total & $\begin{array}{l}\text { Dedicated } \\
\text { ministry of } \\
\text { health }\end{array}$ & $\begin{array}{l}\text { Ministry } \\
\text { of health } \\
\text { with } \\
\text { other } \\
\text { sectors } \\
\text { lumped }\end{array}$ & $\begin{array}{l}\text { Health } \\
\text { at sub- } \\
\text { sectoral } \\
\text { level in } \\
\text { another } \\
\text { ministry }\end{array}$ \\
\hline $\begin{array}{l}\text { All WHO } \\
\text { member } \\
\text { states }\end{array}$ & 194 & $\begin{array}{l}143 \\
(74 \%)\end{array}$ & $46(24 \%)$ & $5(2 \%)$ \\
\hline $\begin{array}{l}\text { Countries } \\
\text { with } \\
\text { population } \\
\text { comparable } \\
\text { to Nepal's, } \\
\text { i.e. } 28.5 \pm \\
5 \text { million }\end{array}$ & 14 & $11(79 \%)$ & $3(21 \%)$ & -- \\
\hline $\begin{array}{l}\text { Countries } \\
\text { with } \\
\text { population } \leq \\
28.5 \text { million } \\
\text { (Nepal) }\end{array}$ & 148 & $\begin{array}{l}108 \\
(73 \%)\end{array}$ & $35(24 \%)$ & $5(3 \%)$ \\
\hline $\begin{array}{l}\text { Federal } \\
\text { countries }\end{array}$ & 25 & 17 (68\%) & $7(28 \%)$ & $1(4 \%)$ \\
\hline $\begin{array}{l}\text { Countries } \\
\text { with } \\
\text { population } \\
\leq 4 \text { million } \\
\text { (comparable } \\
\text { to the } \\
\text { population } \\
\text { of a Nepali } \\
\text { province) }\end{array}$ & 68 & $47(69 \%)$ & $18(27 \%)$ & $3(4 \%)$ \\
\hline
\end{tabular}


- Health sector organisation in the absence of a dedicated ministy of health

What are sectors that are kept together with ministry of health in countries, where a dedicated ministry of health does not form part of the governance? As indicated above, in 46 or $24 \%$ countries worldwide other sectors are combined with $\mathrm{MOH}$

Figure 6 depicts that in $25(54 \%)$ countries, $\mathrm{MOH}$ is combined with social welfare/ security, in 5 countries (11\%) with Environment, and in 8 (17\%) with Population, Family Welfare and Planning. In 8 countries

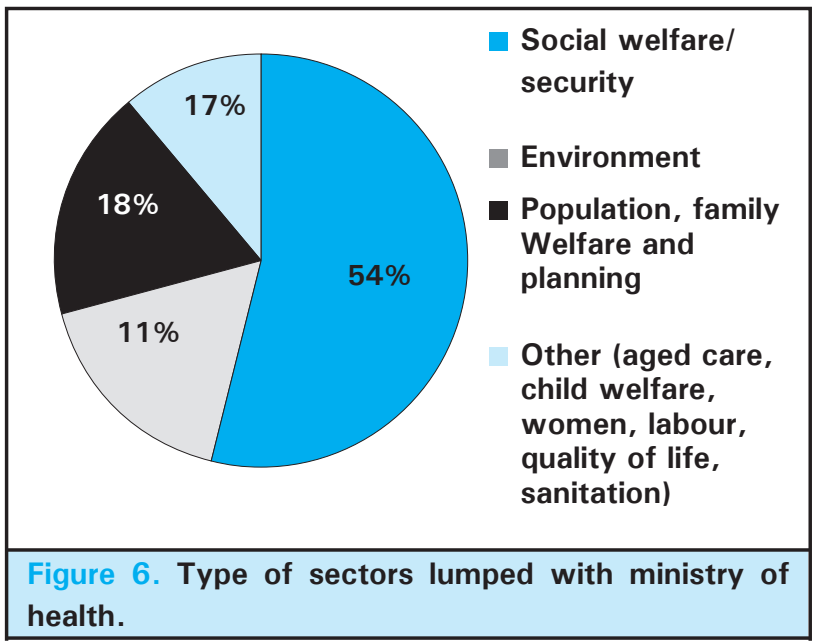

$(17 \%)$, 'other sectors', i.e. aged care, child welfare, women, labour, quality of life, sanitation are part of the ministry that also includes health. In summary, in all these countries, the $\mathrm{MOH}$ is incorporated in a Ministry that also cover other sectors related to health or which are certain aspects or sub-sectors of health. In conclusion, in the vast majority of countries a Ministry of Health is established to guide the health sector, either as a separate entity or included in an entity that covers a broader health-related sector.

- Experience of countries that abolished the ministry of health

Pakistan, according to its constitution (1971), is a federal country with health on provincial as well as concurrent legislative lists of powers. Resultantly, each province as well as the federation had a ministry of health. But, through 18th amendment (April, 2010), the concurrent legislative list of powers was abolished from the constitution. This led to the abolishment of the federal ministry of health and transferring its assets and functions to provinces. This unfortunately caused so much confusion and issues that the country had to recreate a federal level "Ministry of National Health
Services, Regulations and Coordination". Likewise, Kenya, in 2008 opted to divide the Ministry of Health into Ministry of Public Health and Ministry of Medical Services. However, after only 4 years, this decision was revoked and both these ministries were merged and converted back to a Ministry of Health in 2013.

The experience of Pakistan and Kenya shows us that retaining a $\mathrm{MOH}$ can be important; and depending on the country, such $\mathrm{MOH}$ can be at national level, or at national and provincial levels. The legislative lists of powers defined in the Constitution for the governance levels are important to avoid duplication or gaps in functions between levels.

- Status of health ministry in governance structure: is a provincial ministry of health justified in nepali provinces?

Under the new federal system, Nepal has seven provinces, each with an average population of four million. Whether or not a $\mathrm{MOH}$ be established for such a small population (i.e. 4 million)? While responding to this question, we considered other factors discussed in section 2 applicable equally to this political unit. We looked at countries with a population size below or equal to 4 million and found that there are 68 countries with population $\leq$ four million people. Out of these, 47 or $69 \%$ countries have a dedicated ministry of health, while 18 or $27 \%$ had other sectors, essentially allied to health merged with ministry of health, and in 3 or $4 \%$, health was at the sub-sectoral level of another ministry (Figure 7). Given the observation that in $69 \%$ countries around the world with a population $\leq$ four million people have a dedicated ministry of health; one may logically conclude that each Nepali province should also have a $\mathrm{MOH}$.

\section{WAY FORWARD}

Currently, the Nepal Ministry of Health is overseeing health services provision. With the country becoming a federal state however, while there is growing political consensus to have a Federal Ministry of Health, Health at center whether or not will there be Provincial Ministries of Health is unclear.

The Nepal Constitution places great emphasis on the health in a devolved set up; and it is incumbent on the politicians to ensure it is reflected in the national priorities and the state structure. Merely retaining a Ministry of Health at federal level could be construed a continuation of the hitherto unitary system and would hardly translate the constitutional will of devolution, i.e. transfer of powers to lowers tiers in government.

Furthermore, in order the Nepali people receive the required quality healthcare and, an elaborate health 
system hierarchy from the capital at top to provinces and down to the district and village levels should be established. That is, in the new federated structure, in addition to a Federal Ministry of Health, in each province a Provincial Ministry of Health and on the analogy of District Coordination Committee in each district a District Health Sector Coordination Committee may be established as deconcentrated unit.

The Nepali health system organised in the above manner is more likely to ensure preventive, promotive and curative health service to all, i.e. universal health coverage and for Nepal to meet its global commitments, especially SDGs

\section{ACKNOWLEDGEMENTS}

We acknowledge the valuable contribution of Dr. Jos Vandelaer for this article.

Conflict of Interest: None.

\section{REFERENCES}

1. Decentralization: a sampling of definitions. Working paper prepared in connection with the Joint UNDP-Government of Germany evaluation of the UNDP role in decentralization and local governance. UNDP. 1999. [Full Text]

2. Declaration of Alma-Ata. International Conference on Primary Health Care, Alma-Ata, USSR, 6-12September 1978 (Online). [cited 2017 Jun 10]. [Full Text]

3. Health in All Policies - Framework for Country Action (Online). 2013 May 09 [cited 2017 Jun 10]. [Full Text]
4. National Planning Commission, Government of Nepal. Sustainable Development Goals for Nepal (2016-2030) (National Preliminary Report) (Online). [cited 2017 Jun 11]. [Full Text]

5. Ministries of health worldwide. Geneva Foundation for Medical Education and Research. [cited 2017 Jun 12]. [Full Text]

6. Sania Nishtar. Health and the 18th amendment: retaining national functions in devolution (Online). [cited 2017 Jun 12]. [Full Text] 